\title{
Comprehensive update on current outbreak of novel coronavirus infection (2019-nCoV)
}

\author{
Kamal Kant Sahu ${ }^{1}$, Ajay Kumar Mishra ${ }^{1}$, Amos Lal ${ }^{2}$ \\ ${ }^{1}$ Department of Internal Medicine, Saint Vincent Hospital, Worcester, MA, USA; ${ }^{2}$ Division of Pulmonary and Critical Care Medicine, Mayo Clinic, \\ Rochester, MN, USA \\ Contributions: (I) Conception and design: All authors; (II) Administrative support: All authors; (III) Provision of study materials or patients: All \\ authors; (IV) Collection and assembly of data: All authors; (V) Data analysis and interpretation: All authors; (VI) Manuscript writing: All authors; (VII) \\ Final approval of manuscript: All authors. \\ Correspondence to: Amos Lal, MBBS, MD. (https://orcid.org/0000-0002-0021-2033). Division of Pulmonary and Critical Care Medicine, Mayo Clinic, \\ Rochester, MN, USA. Email: lal.amos@mayo.edu.
}

\begin{abstract}
Recently, a new coronavirus disease (COVID-19) has emerged as a respiratory infection with significant concern for global public health hazards. With an initial suspicion of the animal to the human transmission for earlier cases, now the paradigm has shifted towards human to human transmission via droplets, contacts and/or through fomites. with each passing day, more and more confirmed cases are being reported worldwide which has alarmed the global authorities including World Health Organization (WHO), Centers for Disease Control and Prevention (CDC) and the National Health Commission of the People's Republic of China to take immediate action in order to reduce the transmission and subsequent mortalities associated with COVID-19 to as minimum as possible. Unfortunately, like the previous Coronavirus outbreaks, there is no definite antiviral therapy for the treatment of confirmed cases and hence preventing ourselves from contracting $2019-\mathrm{nCoV}$ is the best way to prevent it from becoming pandemic. Herein, we aim to discuss the latest updates on the origin, genomic characteristics, diagnosis, treatment options and current efforts being made by international health organizations with regards to the 2019-nCoV outbreak.
\end{abstract}

Keywords: Respiratory disease; viral infection; coronavirus; World Health Organization; quarantine period

Submitted Feb 18, 2020. Accepted for publication Mar 17, 2020.

doi: 10.21037/atm.2020.02.92

View this article at: http://dx.doi.org/10.21037/atm.2020.02.92

\section{Introduction}

Recently, a new coronavirus strain has become a matter of concern for human lives (1). Since the beginning of 21 st Century, the current coronavirus outbreak is the third coronavirus attack, the previous one being Severe acute respiratory syndrome-related coronavirus (SARS-CoV) epidemic [2003] and Middle East respiratory syndrome coronavirus (MERS-CoV) epidemic [2012] (Figure 1). On 31 December 2019, clusters of acute respiratory illness cases were reported among people associated with the Hunan seafood and animal market in the city of Wuhan, China. Within 1 month of reporting of novel coronavirus associated acute respiratory illness, more than 70,000 confirmed cases have been reported with a reported mortality of around $2 \%$ to $3 \%$ in these patients (2-4). This outbreak also seems to be challenging to manage just like the previous coronavirus outbreaks considering the rapid spread via droplets and non availability of any effective vaccines or antiviral drugs.

\section{Epidemiology}

\section{Demographic spread}

Recently, a new coronavirus strain has become a matter of concern for human lives (1). Since the beginning of the 21 st Century, the current coronavirus outbreak is the third coronavirus attack, the previous one being Severe 

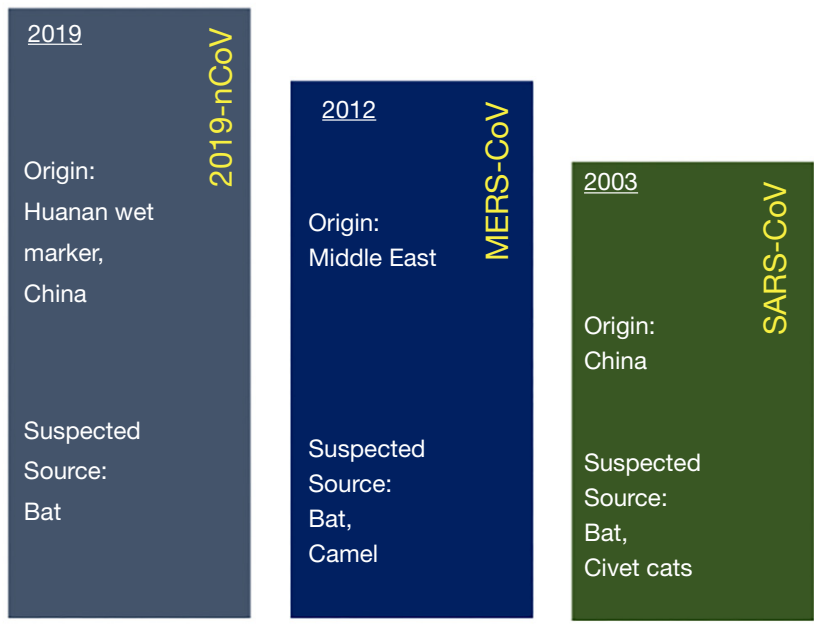

Figure 1 A pictorial description of demographical origin and the suspected source of the all the three coronavirus outbreaks (SARSCoV, MERS-CoV, and 2019-nCoV infection).

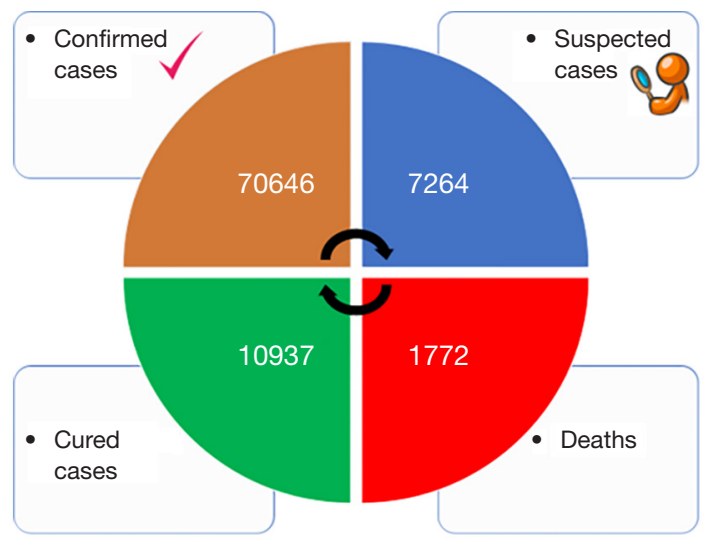

Courtesy: http://h5.peopleapp.com/covid19/ (updated till 02/18/2020)

Figure 2 Total number of confirmed, suspected, cured and death cases within China (updated till 02/18/2020).

acute respiratory syndrome-related coronavirus (SARS$\mathrm{CoV}$ ) epidemic in 2003 and the Middle East respiratory syndrome coronavirus (MERS-CoV) epidemic in 2012 (Figure 1). In December 2019, clusters of acute respiratory illness cases were reported among people associated with the Hunan seafood and animal market in the city of Wuhan, China. Within 1 month of reporting of a novel coronavirus associated acute respiratory illness, more than 70,000 confirmed cases have been confirmed with a reported mortality of around $2 \%$ to $3 \%$ in these patients (2-4). In China alone, the total number of confirmed COVID-2019
Table 1 Epidemiological data of total confirmed, cured and died cases in China

\begin{tabular}{|c|c|c|c|}
\hline Area & $\begin{array}{l}\text { Confirmed } \\
\text { cases }\end{array}$ & $\begin{array}{l}\text { Cure } \\
\text { cases }\end{array}$ & Death \\
\hline Hubei province & 58,182 & 6,639 & 1,696 \\
\hline Guangdong province & 1,322 & 473 & 4 \\
\hline Henan province & 1,246 & 438 & 16 \\
\hline Zhejiang province & 1,171 & 470 & 0 \\
\hline Hunan province & 1,006 & 467 & 3 \\
\hline Anhui province & 973 & 293 & 6 \\
\hline Jiangxi province & 930 & 275 & 1 \\
\hline Jiangsu province & 626 & 226 & 0 \\
\hline Chongqing & 552 & 210 & 5 \\
\hline Shandong province & 541 & 182 & 2 \\
\hline Sichuan province & 495 & 136 & 3 \\
\hline Heilongjiang province & 457 & 80 & 11 \\
\hline Beijing & 381 & 114 & 4 \\
\hline Shanghai & 332 & 161 & 1 \\
\hline Hebei province & 301 & 109 & 3 \\
\hline Fujian province & 290 & 84 & 0 \\
\hline Shaanxi province & 240 & 74 & 0 \\
\hline Guangxi Zhuang Autonomous Region & 238 & 51 & 2 \\
\hline Yunnan province & 171 & 47 & 0 \\
\hline Hainan & 163 & 52 & 4 \\
\hline Guizhou province & 146 & 55 & 1 \\
\hline Shanxi province & 129 & 50 & 0 \\
\hline Tianjin & 125 & 46 & 3 \\
\hline Liaoning province & 121 & 41 & 1 \\
\hline Gansu province & 91 & 58 & 2 \\
\hline Jilin province & 89 & 30 & 1 \\
\hline Xinjiang Uygur Autonomous Region & 75 & 12 & 1 \\
\hline Inner Mongolia Autonomous Region & 72 & 8 & 0 \\
\hline Ningxia Hui Autonomous Region & 70 & 33 & 0 \\
\hline $\begin{array}{l}\text { Hong Kong Special Administrative } \\
\text { Region }\end{array}$ & 60 & 2 & 1 \\
\hline Taiwan province & 22 & 2 & 1 \\
\hline Qinghai province & 18 & 13 & 0 \\
\hline Macao Special Administrative Region & 10 & 5 & 0 \\
\hline Tibet Autonomous Region & 1 & 1 & 0 \\
\hline Grand total & 70,646 & 10,937 & 1,772 \\
\hline
\end{tabular}

Courtesy: http://h5.peopleapp.com/covid19/ (updated till 02/18/2020) 
Table 2 Epidemiological data of total confirmed, cured and died cases worldwide

\begin{tabular}{|c|c|c|c|}
\hline Area & Confirmed cases & Cure cases & Death \\
\hline Japan & 519 & 1 & 1 \\
\hline Singapore & 75 & 19 & 0 \\
\hline Thailand & 35 & 14 & 0 \\
\hline Korea & 30 & 10 & 0 \\
\hline Malaysia & 22 & 9 & 0 \\
\hline Vietnam & 16 & 7 & 0 \\
\hline Germany & 16 & 1 & 0 \\
\hline United States & 15 & 3 & 0 \\
\hline Australia & 15 & 5 & 0 \\
\hline France & 12 & 4 & 1 \\
\hline United Arab Emirates & 9 & 4 & 0 \\
\hline United Kingdom & 9 & 8 & 0 \\
\hline Canada & 8 & 1 & 0 \\
\hline Italy & 3 & 0 & 0 \\
\hline India & 3 & 0 & 0 \\
\hline Philippines & 3 & 0 & 1 \\
\hline Russia & 2 & 0 & 0 \\
\hline Spain & 2 & 0 & 0 \\
\hline Sri Lanka & 1 & 1 & 0 \\
\hline Cambodia & 1 & 0 & 0 \\
\hline Finland & 1 & 1 & 0 \\
\hline Sweden & 1 & 0 & 0 \\
\hline Belgium & 1 & 0 & 0 \\
\hline Nepal & 1 & 0 & 0 \\
\hline Egypt & 1 & 0 & 0 \\
\hline Grand total & 801 & 88 & 3 \\
\hline
\end{tabular}

Courtesy: http://h5.peopleapp.com/covid19/ (updated till 02/18/2020).

cases reported till 18th January 2020 is 70,646 with another 7,264 suspected to have COVID-2019 and are pending test results (Figure 2). Excluding China, around 801 laboratoryconfirmed cases have been reported from 25 countries worldwide. The bulk of these cases are reported mostly from Japan, Singapore, Thailand, and Korea. As of 18th February 2020, 15 confirmed cases have been reported in the United States (5). While 1,772 deaths have been reported among patients suffering from COVID-2019 in China alone, only 3 deaths have been reported worldwide 1 each from Japan, Thailand, and the Philippines (Tables 1,2).

\section{Zoonotic component of 2019-nCoV}

While we still do not know the exact source of origin of 2019-nCoV, the early cases were speculated to be the result of animal-to-person spread with a possible epidemiological link to the Huanan seafood wholesale market (6). As the subsequent cases were reported even in individuals without any exposure to animal markets, it is now thought that the growing number of cases are secondary to the subsequent person to person contact (Figure 3). Metagenomic analysis using next-generation sequencing has shown that this virus has $96.2 \%$ homology to a bat virus and shares $79.5 \%$ of its genetic sequence with SARS-CoV (6).

\section{Genomics analysis of 2019-nCoV}

Coronavirus, an enveloped positive-sense RNA virus has multiple club-like spikes on its surface which give an appearance of Sun's corona during a total solar eclipse. The family Coronaviridae incorporates many viruses predominately found in birds and mammals (Figure 4). It was in the 1960s, when a large percentage of respiratory infections in humans were traced to be related to coronaviruses and henceforth it was postulated that, humans could also become accidental hosts in case of contact with wild and exotic animals. 2019-nCoV is being studied for its genetics by researchers and scientists worldwide and the recent report by Paraskevis et al. suggests its genomes to be nonmosaic thereby rejecting a hypothesis of a possibility of recent recombination event as the cause of this outbreak (7). Instead, there is a possibility of COVID-2019 to be originating from bat considering its close similarity to bat coronavirus. However, more dedicated studies are needed to understand additional insights about its pathogenesis and origin.

\section{Approach to a suspected case}

It is important for the health care professionals to understand the steps which need to be followed in case of suspicion of COVID-2019 in any of their patients. $\mathrm{WHO}$ and CDC have issued statements regarding when to suspect? Whom to suspect? And how to approach? Initially, suspected case definition [NCIP (Novel coronavirus infected pneumonia)] was based on the previous 


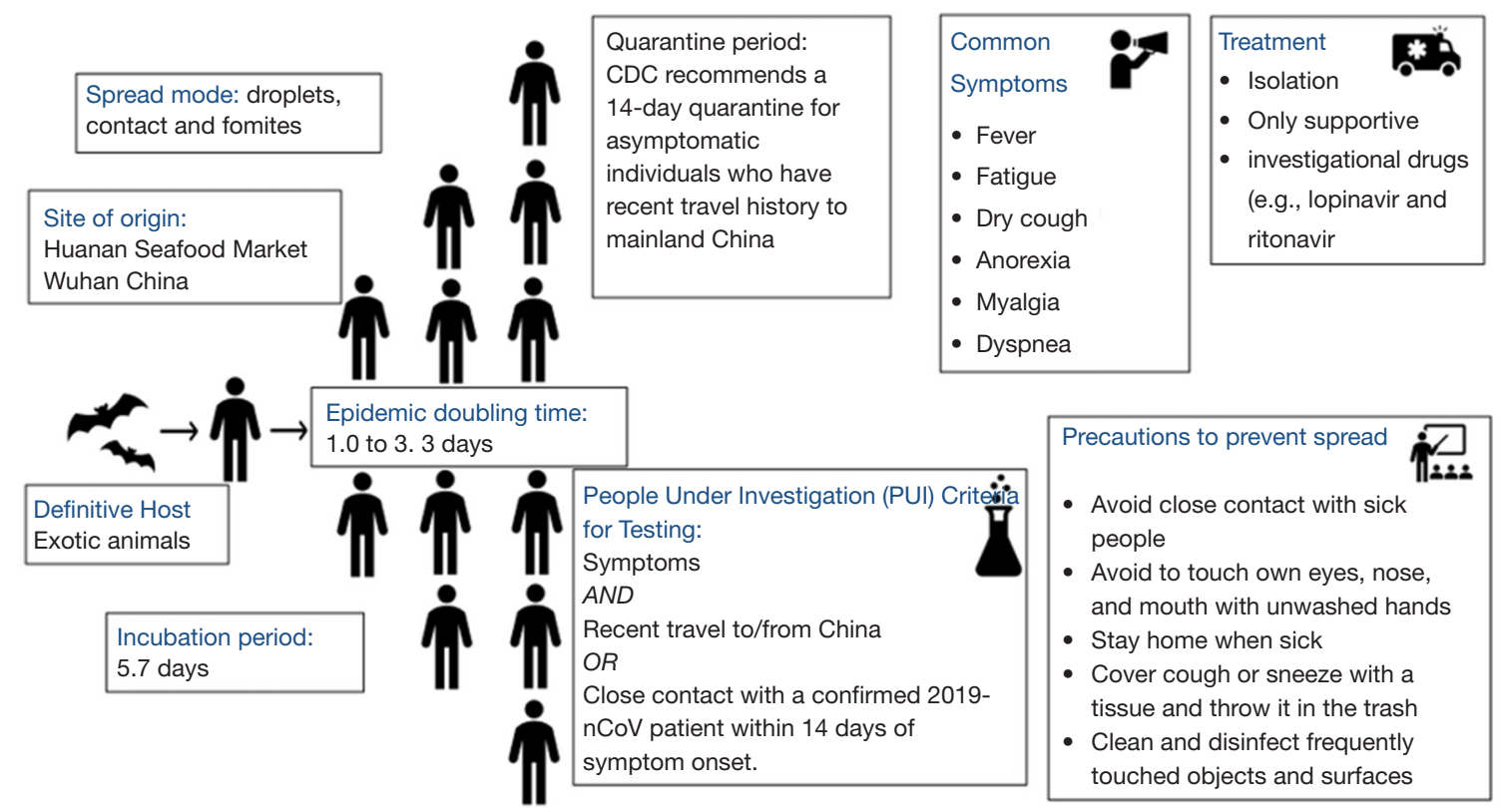

Figure 3 A proposed pictorial description of various phases of dissemination of 2019-nCoV from animals to humans, symptoms, available treatment strategies, and preventive measures.

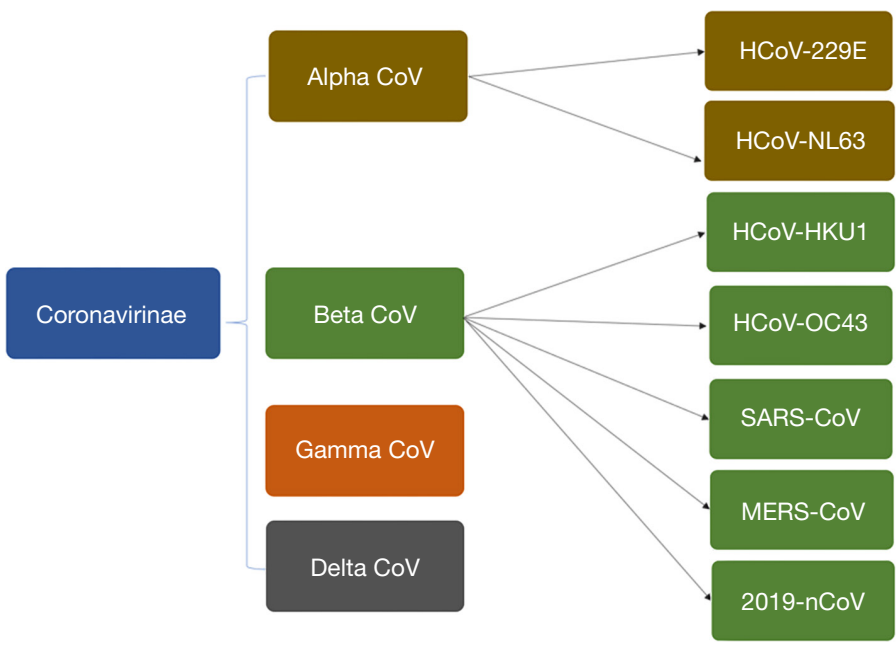

Figure 4 The figure describing Coronavirinae family and subgroups with the new addition of 2019-nCoV in the beta-CoV subgroup.

experiences with MERS and SARS virus outbreaks. Later, on $18^{\text {th }}$ January 2020 , WHO modified the definition that categorically removed the laboratory and imaging criteria in order to expedite the diagnosis. Hence, now the new criteria of suspected case is based on clinical and travel history alone, which is helping to investigate and isolate suspected cases without any further delay (8) (Table 3).

It is expected that health care professionals be thorough with the stepwise approach to investigate any case of COVID-2019 as per CDC guidelines (9). Through a flowchart, we simplified the guidelines in a stepwise fashion (Figure 5). 
Table 3 Criteria laid down by WHO for the suspected case, NCIP, close contact and people under investigation

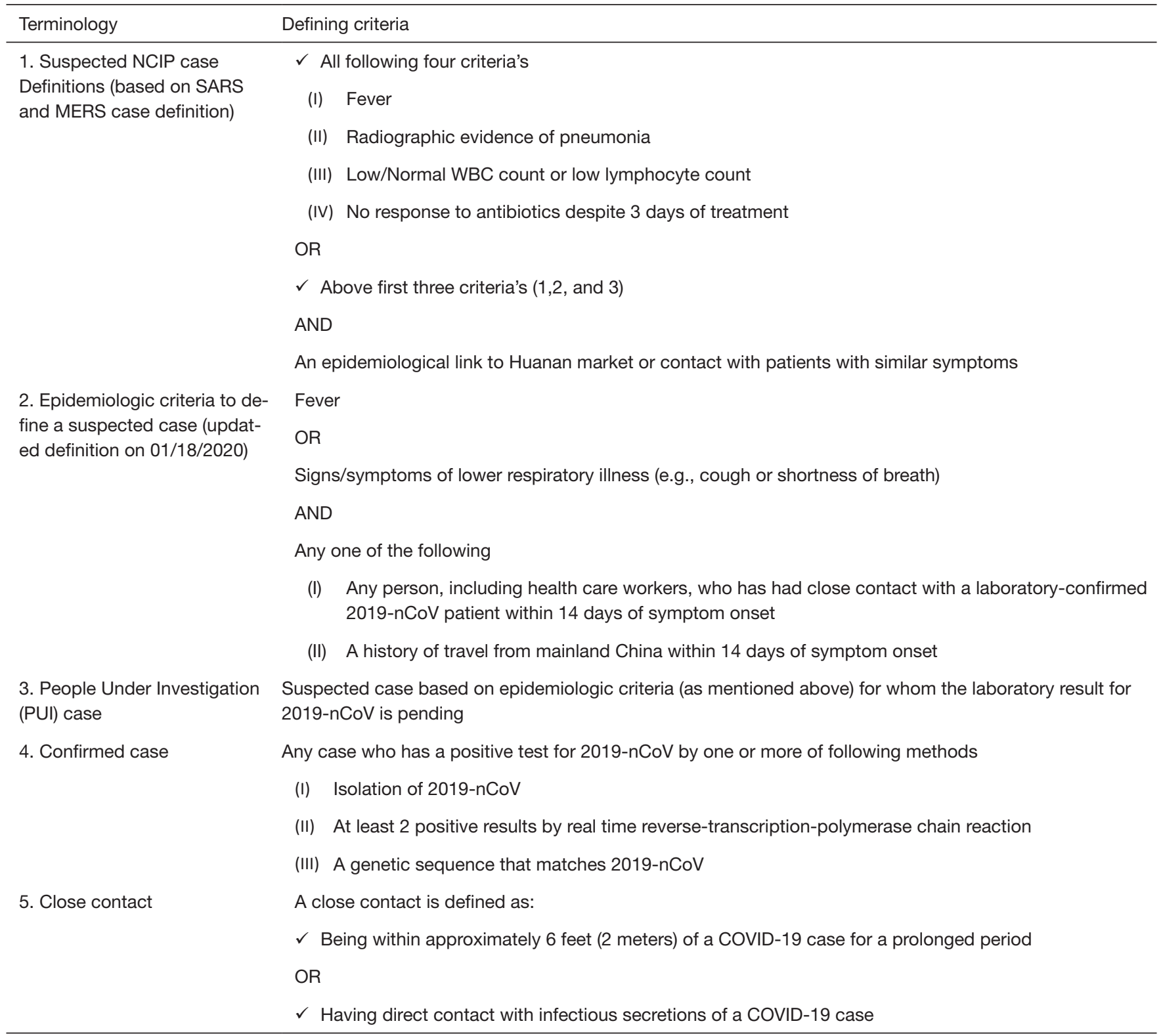
NCIP, novel coronavirus infected pneumonia; COVID-19, Coronavirus disease 2019; SARS, severe acute respiratory syndrome-related coronavirus; MERS, Middle East respiratory syndrome coronavirus; PUI, People Under Investigation.

\section{Clinical features, lab abnormalities and treatment outcome based on available literature}

Many observational studies mostly being reported from Mainland China have described the clinical features, treatment given and outcomes of the patients suffering from COVID-2019 induced NCIP. Wang et al. from the Hospital of Wuhan University have studied 138 infected and hospitalized patients (10). The median age reported was
56 years and predominantly affecting the males. Common symptoms reported were fever (98.6\%), fatigue (69.6\%) followed by dry cough (59.4\%). With regards to laboratory workup, patients were found to have lymphopenia (70.3\%), deranged coagulogram (58\%), elevated lactic acid dehydrogenase (39.9\%) and abnormal imaging findings (100\%). The most common imaging findings were bilateral patchy shadows and ground-glass opacities. Patients were treated with varied treatment regimens including antiviral 
STEP 1: Whom to suspect?

Fever or signs/symptoms of lower respiratory illness (e.g. cough or shortness of breath)
AND
any one of the following
-Any person, including health care workers, who has had close contact with a laboratory-confirmed 2019-nCoV patient within 14 days
of symptom onset.
-A history of travel from mainland China within 14 days of symptom onset

STEP 2: Whom to inform?

To immediately report both infection control personnel at healthcare facility and the local or state health department. $\downarrow$

Subsequently, immediately state health department contacts CDC's Emergency Operations Center (EOC) at 770-488-7100 and completes a 2019-nCoV People Under Investigation (PUI) case investigation form available freely at (https://www.cdc.gov/ coronavirus/2019-ncov/downloads/pui-form.pdf)

STEP 3: How to test?

CDC's Emergency Operations Center subsequently will assist state health departments to collect, store, and ship specimens appropriately to CDC. This facility is available during weekends/holidays and afterhours.

STEP 4: What are the cautions while testing?

CDC recommends that sample should not be sent anywhere else as at this time, as diagnostic testing for 2019-nCoV can be conducted only at CDC.

$\checkmark$ CDC does not recommend performing virus isolation from People Under Investigation (PUI).

$\checkmark$ CDC recommends not to delay the shipping of specimens while testing locally for other respiratory pathogens.

$\checkmark$ CDC recommends collecting numerous specimens from different sites, including two specimen types-lower respiratory and upper respiratory.

$\checkmark$ CDC recommends collecting additional specimen types (e.g., stool, urine).

CDC recommends collecting specimens as soon as possible once a PUI is identified irrespective of time of symptom onset.

Figure 5 A stepwise approach to a suspected case of 2019-nCoV based on CDC guidelines.

agents (oseltamivir), antibacterial agents (moxifloxacin, azithromycin, and ceftriaxone) and steroids. Twentysix point four percent of patients required intensive care unit (ICU) support with the majority requiring invasive ventilation. The patients of older age group (66 vs. 51 years) and with underlying comorbidities $(72.2 \%$ vs. $30.6 \%)$ had more likelihood of requiring ICU level care. The most common complications reported were acute respiratory distress syndrome (61.1\%), arrhythmia (44.4\%), and shock (30.6\%). The other complications noted were acute cardiac injury, acute renal injury, pneumothorax, and secondary bacterial infections. Hypertension (31\%), followed by cardiovascular disease (14.5\%), and diabetes mellitus $(10 \%)$ were the top co-existing comorbidities. The average duration of hospital stay amongst the individuals who were discharged was 10 days. The overall reported mortality rate was $4.3 \%$.

Another study by Huang et al. reported from the central hospital of Wuhan included 41 COVID-2019 patients (11). When compared with Wang et al.'s cohort, Huang et al.'s patient population were comparatively younger (median age of $49 v s .56$ years) and with lower mortality rate (3\% vs. $4.3 \%)$. Both study groups had the same top 3 clinical features (fever, fatigue, and cough) and underlying comorbidities (hypertension, diabetes mellitus, and cardiovascular disorders). In general, viral infections are known to have the worst outcome for immunocompromised individuals (12-18). The similar results of different studies in terms of clinical presentation, underlying comorbidities and mortality rates would certainly be helpful to health professionals to triage and risk stratify the patient population who might require a high level of care $(10,11,19-21)$. As per the latest available data, the total number of deaths related to COVID-2019 is the highest of all the three coronavirus outbreaks of the 21 st century. However, until now, the mortality rate secondary to COVID-2019 is the lowest of all, with the highest being associated with MERS$\mathrm{CoV}(35 \%)$ followed by SARS-CoV (9.6\%) and 2019$\mathrm{nCoV}(2.72 \%)$ (Figure 6).

\section{Newer drugs and active clinical trials}

Since the time of COVID-2019 outbreak, there has been a sudden surge in the number of clinical trials getting 

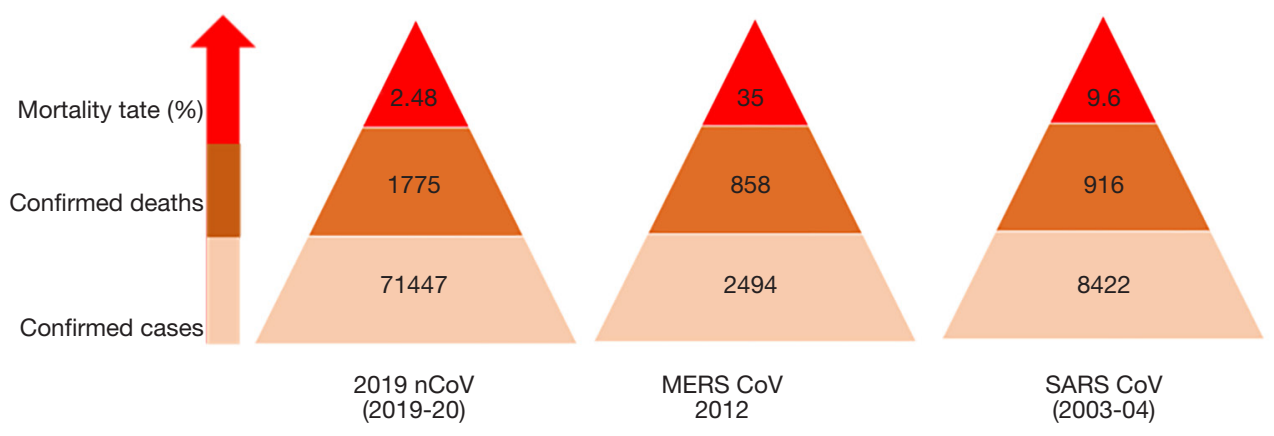

Figure 6 Comparing confirmed cases, total deaths and mortality rates worldwide between three coronavirus outbreaks of 21 st Century ( 2019-nCoV versus MERS CoV versus SARS CoV).

approved for studying various aspects of 2019-nCoV infection, its pathogenesis, symptomatology, complications and newer diagnostic and treatment alternatives $(22,23)$. As per the clinicaltrials.gov, we found many clinical trials actively recruiting patients with most of the studies being initiated in Chinese hospitals (Table 4). For example, there are studies looking into the impact of COVID-2019 on the cardiovascular system (Gov Identifier: NCT04255940) or on psychological status of health care professionals ( $\mathrm{Gov}$ Identifier: NCT04260308). Similarly, there are clinical trials exploring newer treatment options like hydroxyquinoline (Gov Identifier: NCT04261517), methylprednisone (Gov Identifier: NCT04263402), Immunoglobulin (Gov Identifier: NCT04261426), Darunavir/Cobicistat (Gov Identifier: NCT04252274), Lopinavir/Ritonavir (Gov Identifier: NCT04261907) and so on. WHO and the National Health Commission of the People's Republic of China have allotted separate financial aid as well for conducting studies. While we appreciate every attempt that could help in better treatment of the patients affected with this deadly virus, the results of these trials would not be available in near future to be of immediate benefit to the presently affected population. Hence, based on the experiences with previous coronavirus outbreaks, we believe that supportive treatment is the best way to treat a patient and exercising all the precautionary and preventive measures is the only way to avoid ourselves from acquiring infection.

\section{Hospital policies and preparedness}

\section{Employee, patient, community safety—hospital's priority}

Every hospital, be it a community health center or a university or an academic center is expected to be vigilant, resourceful, and upgraded to tackle any COVID-2019 case efficiently. Every hospital should have dedicated task force coordinating the hospital's internal processes and resources to promote effective and safe management of any local outbreak of the coronavirus, if the situation arises. Also, it would be desirable for the special task force to work closely with the local health department and the Centers for Disease Control and Prevention (CDC) to prepare and respond to any potential $2019-\mathrm{nCoV}$ cases that may present to the hospital. There should be special seminars and educational sessions for health care workers focusing on CDC guidelines for identification and treatment of patients with suspected or confirmed cases of the coronavirus.

\section{Additional precautions in hospitals}

\section{Signage}

Posting signage at all entries, in several languages, advising patients or visitors to alert staff immediately regarding recent travel, current symptoms, and/or close contact with someone who fits these criteria.

\section{Screening}

Asking all patients the CDC screening questions. Symptoms including fever, cough, or shortness of breath. In addition, travel questions including travel to Hubei Province and/ or mainland China. Finally, also asking about close contact with a confirmed coronavirus patient, or someone who has traveled from mainland China with symptoms requiring hospitalization, within the last two weeks.

\section{Personal protective supplies}

To ensure that the hospital provides adequate supplies of personal protective equipments, such as gowns, gloves, masks, face shields, and goggles to its staff and physicians. 
Table 4 Recent clinical trials actively recruiting/studying various aspects of 2019-nCoV characteristics, newer diagnostics and treatment options

\begin{tabular}{|c|c|c|c|c|c|}
\hline $\begin{array}{l}\text { Clinical trials.gov } \\
\text { identifier }\end{array}$ & Status & Study type & $\begin{array}{l}\text { Expectant } \\
\text { participants }\end{array}$ & Study title & Country \\
\hline NCT04262921 & $\begin{array}{l}\text { Active \& } \\
\text { Recruiting }\end{array}$ & Observational & 500 & $\begin{array}{l}\text { Clinical Characterisation Protocol for Severe Emerging Infections } \\
\text { (CCP-nCoV) }\end{array}$ & France \\
\hline NCT04244591 & $\begin{array}{l}\text { Active \& } \\
\text { Recruiting }\end{array}$ & Interventional & 80 & $\begin{array}{l}\text { Glucocorticoid Therapy for Novel Coronavirus Critically III Patients } \\
\text { with Severe Acute Respiratory Failure (Steroids-SARI) }\end{array}$ & China \\
\hline NCT04261517 & $\begin{array}{l}\text { Active, not yet } \\
\text { recruiting }\end{array}$ & Interventional & 30 & $\begin{array}{l}\text { Efficacy and Safety of Hydroxychloroquine for Treatment of } \\
\text { Pneumonia Caused by 2019-nCoV (HC-nCoV) }\end{array}$ & China \\
\hline NCT04259892 & $\begin{array}{l}\text { Active \& } \\
\text { Recruiting }\end{array}$ & Observational & 300 & $\begin{array}{l}\text { Viral Excretion in Contact Subjects at High/Moderate Risk of } \\
\text { Coronavirus 2019-nCoV Infection (Cov-CONTACT) }\end{array}$ & France \\
\hline NCT04255940 & $\begin{array}{l}\text { Active \& } \\
\text { Recruiting }\end{array}$ & Observational & 12,000 & 2019-nCoV Outbreak and Cardiovascular Diseases & China \\
\hline NCT04256395 & $\begin{array}{l}\text { Active \& } \\
\text { Recruiting }\end{array}$ & Observational & 100,000 & $\begin{array}{l}\text { Efficacy of a Self-test and Self-alert Mobile Applet in Detecting } \\
\text { Susceptible Infection of 2019-nCoV (2019-nCoV) }\end{array}$ & China \\
\hline NCT04264533 & $\begin{array}{l}\text { Active, not yet } \\
\text { recruiting }\end{array}$ & Interventional & 140 & $\begin{array}{l}\text { Vitamin C Infusion for the Treatment of Severe 2019-nCoV Infected } \\
\text { Pneumonia }\end{array}$ & China \\
\hline NCT04261907 & $\begin{array}{l}\text { Active, not yet } \\
\text { recruiting }\end{array}$ & Interventional & 160 & $\begin{array}{l}\text { Evaluating and Comparing the Safety and Efficiency of ASC09/ } \\
\text { Ritonavir and Lopinavir/Ritonavir for Novel Coronavirus Infection }\end{array}$ & China \\
\hline NCT04260308 & $\begin{array}{l}\text { Active \& } \\
\text { Recruiting }\end{array}$ & Observational & 30,000 & $\begin{array}{l}\text { A Survey of Psychological Status of Medical Workers and } \\
\text { Residents in the Context of } 2019 \text { Novel Coronavirus Pneumonia }\end{array}$ & China \\
\hline NCT04260594 & $\begin{array}{l}\text { Active, not yet } \\
\text { recruiting }\end{array}$ & Interventional & 380 & $\begin{array}{l}\text { Clinical Study of Arbidol Hydrochloride Tablets in the Treatment of } \\
\text { Pneumonia Caused by Novel Coronavirus }\end{array}$ & China \\
\hline NCT04264858 & $\begin{array}{l}\text { Active, not yet } \\
\text { recruiting }\end{array}$ & Interventional & 10 & $\begin{array}{l}\text { Treatment of Acute Severe 2019-nCoV Pneumonia with } \\
\text { Immunoglobulin from Cured Patients }\end{array}$ & China \\
\hline NCT04263402 & $\begin{array}{l}\text { Active, not yet } \\
\text { recruiting }\end{array}$ & Interventional & 100 & $\begin{array}{l}\text { The Efficacy of Different Hormone Doses in 2019-nCoV Severe } \\
\text { Pneumonia }\end{array}$ & China \\
\hline NCT04261270 & $\begin{array}{l}\text { Active, not yet } \\
\text { recruiting }\end{array}$ & Interventional & 60 & $\begin{array}{l}\text { A Randomized, Open, Controlled Clinical Study to Evaluate the } \\
\text { Efficacy of ASC09F and Ritonavir for 2019-nCoV Pneumonia }\end{array}$ & China \\
\hline NCT04254874 & $\begin{array}{l}\text { Active, not yet } \\
\text { recruiting }\end{array}$ & Interventional & 100 & $\begin{array}{l}\text { A Prospective, Randomized Controlled Clinical Study of Interferon } \\
\text { Atomization in the } 2019-n \text { CoV Pneumonia }\end{array}$ & China \\
\hline
\end{tabular}

Table 4 (continued) 
Table 4 (continued)

\begin{tabular}{|c|c|c|c|c|c|}
\hline $\begin{array}{l}\text { Clinical trials.gov } \\
\text { identifier }\end{array}$ & Status & Study type & $\begin{array}{l}\text { Expectant } \\
\text { participants }\end{array}$ & Study title & Country \\
\hline NCT04255017 & $\begin{array}{l}\text { Active, not yet } \\
\text { recruiting }\end{array}$ & Interventional & 400 & $\begin{array}{l}\text { An Open, Prospective, Randomized Controlled Cohort Study to } \\
\text { Compare the Efficacy of Three Antiviral Drugs (Abidol } \\
\text { Hydrochloride, Oseltamivir and Lopinavir/Ritonavir) in the Treatment } \\
\text { of 2019-nCoV Pneumonia }\end{array}$ & China \\
\hline NCT04261426 & $\begin{array}{l}\text { Active, not yet } \\
\text { recruiting }\end{array}$ & Interventional & 80 & $\begin{array}{l}\text { The Efficacy of Intravenous Immunoglobulin Therapy for Severe } \\
\text { 2019-nCoV Infected Pneumonia }\end{array}$ & China \\
\hline NCT04252664 & $\begin{array}{l}\text { Active, not yet } \\
\text { recruiting }\end{array}$ & Interventional & 308 & $\begin{array}{l}\text { A Phase } 3 \text { Randomized, Double-blind, Placebo-controlled } \\
\text { Multicenter Study to Evaluate the Efficacy and Safety of Remdesivir } \\
\text { in Hospitalized Adult Patients with Mild and Moderate 2019-nCoV } \\
\text { Respiratory Disease }\end{array}$ & China \\
\hline NCT04268537 & $\begin{array}{l}\text { Active, not yet } \\
\text { recruiting }\end{array}$ & Interventional & 120 & $\begin{array}{l}\text { Immunoregulatory Therapy for 2019-nCoV-induced Severe } \\
\text { Pneumonia Patients }\end{array}$ & China \\
\hline NCT04252118 & $\begin{array}{c}\text { Active \& } \\
\text { Recruiting }\end{array}$ & Interventional & 40 & $\begin{array}{l}\text { To assess Safety and Efficiency of Mesenchymal Stem Cell in } \\
\text { Treating Pneumonia Patients Infected With } 2019 \text { Novel Coronavirus }\end{array}$ & China \\
\hline
\end{tabular}

Adopted from: https://clinicaltrials.gov/ct2/results?cond=coronavirus.

\section{Employee guidance}

As an employee, if someone reports having (I) a history of travel from Hubei Province, China, and/or, (II) a history of travel to mainland China requiring subsequent hospitalization, he/she cannot work for 14 days. Similarly, if an employee had close contact with a confirmed case of 2019-nCoV, he/she cannot return to work within 14 days of the last contact. Also, if an employee meets the criteria as described above, he/she should provide a letter from his/her healthcare provider allowing to return to work. However, if an employee has exposure to a confirmed case of 2019$\mathrm{nCoV}$ as a healthcare provider with the use of Personal Protected Equipment in accordance with policy, the abovementioned criteria should not apply.

\section{The need of the hour: a multi-level collaboration}

The 2019-nCoV infection has deeply affected every individual, society, and Nationals all around the world. In the era of free communication, we would like to emphasize the importance of recognizing our responsibilities and fulfilling the expectations of an ideal national (Figure 7). Similarly, we expect and encourage various social media platforms and news channels responsible for broadcasting the latest updates on 2019-nCoV infection and other related subjects to abide by the regulations and try to maintain transparency while reporting. Recently, WHO has even labeled the rumors and fake news floating in various social media platforms as "Infodemic". WHO has even initiated a web page "myth busters" to bust rumors and prevent unnecessary panic (24). WHO has sent an expert team to China and is working in close collaboration with Chinese counterparts in order to try to contain the virus and to study the characteristics of the 2019-nCoV, the reason for the outbreak, source of infection and modes of prevention and treatment.

\section{Health care workers: endangering own's life for community service}

As per the reports from China's National Health Commission, till 16th February a total of 1,716 medical health workers from China alone have been found to be positive for 2019-nCoV, and out of them, 6 health care workers have even lost their life. Most of the health professionals belong to Hubei Providence which is considered as the center of the outbreak. Dr. Li Wenliang, a young 33-year-old ophthalmologist was the whistleblower of the "SARS-like" virus in early December 2019 when the cluster of patients were admitted for pneumonia of unknown etiology. Unfortunately, he died from the 


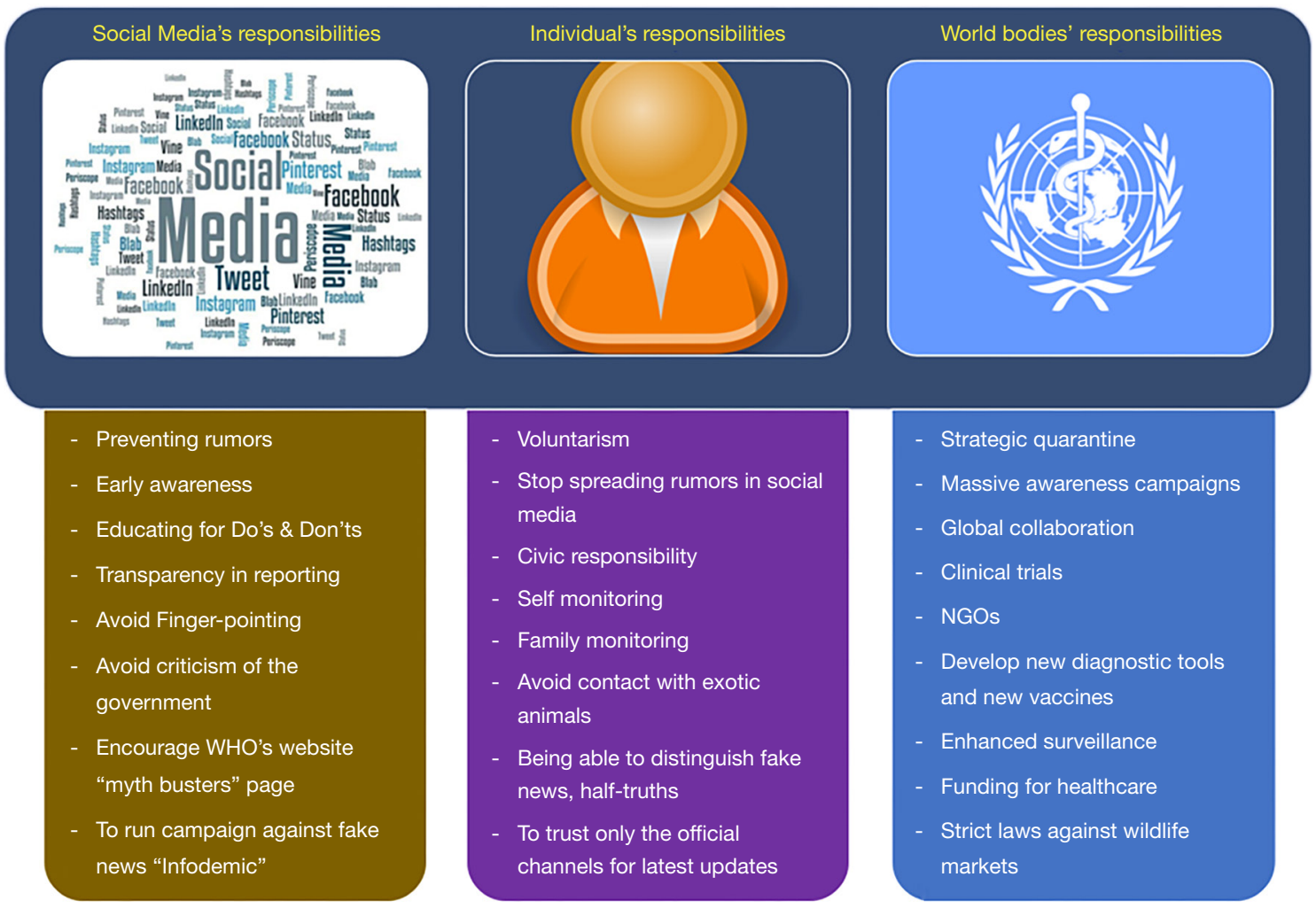

Figure 7 Pictorial descriptions of expected responsibilities of individuals, media houses and international health organizations in containing the spread of 2019-nCoV infection and rumors.

COVID-2019 on February 7, 2020. We would like to pay our regards and homage to all the health care providers including doctors, nurses, staff members, researchers, scientists, and all other officials who in one or the other way are involved in providing their services to the COVID-2019 struck community.

\section{Conclusions}

In conclusion, as of now, we have very little knowledge about 2019-nCoV, and every attempt should be made in order to understand and contain COVID-2019 as early as possible. We hope that the ongoing clinical trials will help us to gain further insights about its genetics, source of origin, pathogenesis, diagnosis, and treatment.

\section{Acknowledgments}

Funding: None.

\section{Footnote}

Conflicts of Interest: The authors have no conflicts of interest to declare.

Ethical Statement: The authors are accountable for all aspects of the work in ensuring that questions related to the accuracy or integrity of any part of the work are appropriately investigated and resolved.

Open Access Statement: This is an Open Access article distributed in accordance with the Creative Commons Attribution-NonCommercial-NoDerivs 4.0 International License (CC BY-NC-ND 4.0), which permits the noncommercial replication and distribution of the article with the strict proviso that no changes or edits are made and the original work is properly cited (including links to both the formal publication through the relevant DOI and the license). See: https://creativecommons.org/licenses/by-nc-nd/4.0/. 


\section{References}

1. Del Rio C, Malani PN. 2019 Novel CoronavirusImportant Information for Clinicians. JAMA 2020. [Epub ahead of print].

2. Chang, Lin M, Wei L, et al. Epidemiologic and Clinical Characteristics of Novel Coronavirus Infections Involving 13 Patients Outside Wuhan, China. JAMA 2020. [Epub ahead of print].

3. Chen J. Pathogenicity and Transmissibility of 2019-nCoV-A Quick Overview and Comparison with Other Emerging Viruses. Microbes Infect 2020. [Epub ahead of print].

4. Available online: http://h5.peopleapp.com/covid19/

5. Available online: https://www.cdc.gov/coronavirus/2019ncov/cases-in-us.html

6. Perlman S. Another Decade, Another Coronavirus. N Engl J Med 2020. [Epub ahead of print].

7. Paraskevis D, Kostaki EG, Magiorkinis G, et al. Fullgenome evolutionary analysis of the novel corona virus (2019-nCoV) rejects the hypothesis of emergence as a result of a recent recombination event. Infect Genet Evol 2020;79:104212. [Epub ahead of print].

8. Li Q, Guan X, Wu P, et al. Early Transmission Dynamics in Wuhan, China, of Novel Coronavirus-Infected Pneumonia. N Engl J Med 2020. [Epub ahead of print].

9. Centers for Disease Control and Prevention. Interim guidance for healthcare professionals: criteria to guide evaluation of patients under investigation (PUI) for 2019nCoV. 2020. Available online: https://www.cdc.gov/ coronavirus/2019-nCoV/clinical-criteria.html. opens in new tab

10. Wang D, Hu B, Hu C, et al. Clinical Characteristics of 138 Hospitalized Patients With 2019 Novel CoronavirusInfected Pneumonia in Wuhan, China. JAMA 2020. [Epub ahead of print].

11. Huang C, Wang Y, Li X, et al. Clinical features of patients infected with 2019 novel coronavirus in Wuhan, China. Lancet 2020;395:497-506.

12. Mishra AK, Sahu KK, James A. Disseminated herpes zoster following treatment with benralizumab. Clin Respir
J 2019;13:189-91.

13. Sahu KK, Prakash G, Khadwal A, et al. A Rare Case of Hemorrhagic Cystitis in Allogeneic Hematopoietic Stem Cell Transplant Patient. Indian J Hematol Blood Transfus 2016;32:196-200.

14. Sahu KK, Varma SC. Herpes zoster complicating bortezomib therapy. Indian J Med Res 2015;141:247-8.

15. Lal A, Akhtar J, Isaac S, et al. Unusual cause of chest pain, Bornholm disease, a forgotten entity; case report and review of literature. Respir Med Case Rep 2018;25:270-3.

16. Lal A, Akhtar J, Ullah A, et al. First Case of Pleural Empyema Caused by Staphylococcus simulans: Review of the Literature. Case Rep Infect Dis 2018;2018:7831284.

17. Lal A, Dhamne MC, Hui AC, et al. Herpes simplex virus (HSV) encephalitis in a young man: an unusual course. BMJ Case Rep 2018. doi: 10.1136/bcr-2017-222499.

18. Lal A, Abraham GM. Utility of CD4 Cell Count and Viral Load Assay in Hospitalized Patients with Known HIV Infection: High Value Care Exercise. Infect Disord Drug Targets 2019. [Epub ahead of print].

19. Chen N, Zhou M, Dong X, et al. Epidemiological and clinical characteristics of 99 cases of 2019 novel coronavirus pneumonia in Wuhan, China: a descriptive study. Lancet 2020;395:507-13.

20. Lal A, Al Hammadi A, Rapose A. Latent Tuberculosis Infection: Treatment Initiation and Completion Rates in Persons Seeking Immigration and Health Care Workers. Am J Med 2019;132:1353-5.

21. Lal A, Akhtar J, Jindal V, et al. Rare Cause of Respiratory Failure: A Twist in the Tale. Ann Am Thorac Soc 2018;15:880-3.

22. Available online: https://clinicaltrials.gov/ct2/ results? cond=coronavirus

23. Patel A, Jernigan DB; 2019-nCoV CDC Response Team. Initial Public Health Response and Interim Clinical Guidance for the 2019 Novel Coronavirus Outbreak United States, December 31, 2019-February 4, 2020. MMWR Morb Mortal Wkly Rep 2020;69:140-6.

24. Available online: https://www.who.int/emergencies/ diseases/novel-coronavirus-2019/advice-for public/mythbusters
Cite this article as: Sahu KK, Mishra AK, Lal A. Comprehensive update on current outbreak of novel coronavirus infection (2019-nCoV). Ann Transl Med 2020;8(6):393. doi: 10.21037/atm.2020.02.92 